\title{
Dr. Alberto Strusberg
}

Estoy segura de que al leer este nombre y ver la foto, la mitad de los lectores recordaron con afecto y nostalgia a aquel "cordobés” que se destacó en la década de los 80 y 90 en la Reumatología argentina, tanto que llegó a ser Presidente de la SAR. La otra mitad, los más jóvenes, recurrieron a Google y encontraron con sorpresa cantidad de páginas y descubrieron que Alberto M. Strusberg nació en Chaco en 1942, y egresó, tras una carrera brillante, como médico de la Universidad Nacional de Córdoba en 1966.

Además encontraron sus especialidades de Reumatólogo, Farmacólogo, Doctor en Medicina e Investigador Clínico, y tal vez se asombraron al ver que había organizado varios Congresos Argentinos de Reumatología y uno del Cono Sur, que había presentado más de 100 Trabajos en Cursos y Congresos, que fue parte de innumerables trabajos de Investigación ClínicaFarmacológica, que también participó en más de 15 Proyectos acreditados y subsidiados por CONICET y SECYT, que dirigió varias Tesis, y que fue autor de varios Capítulos de libros tanto en el área Reumatología como Farmacología, nacionales e internacionales.

Pero la búsqueda en la web, aún minuciosa, no deja traslucir el espíritu inquieto e incansable del Dr. Strusberg, que además de Profesor Titular, Investigador Clínico, Receptor de Exámenes en la Universidad Nacional de Córdoba, y en el Consejo de Médicos de la Provincia, era sobre todo Médico de Consultorio, en contacto diario y estrecho con sus pacientes.

Tampoco se vislumbra en Google, al dinámico personaje, siempre lleno de ideas y proyectos innovadores, que incursionó primero en la Sociedad de Reumatología de Córdoba, llegando muy joven a su Presidencia, para trascender rápidamente a la Sociedad Argentina de Reumatología, donde fue Presidente desde 1991 a 1993, siendo uno de los primeros presidentes del

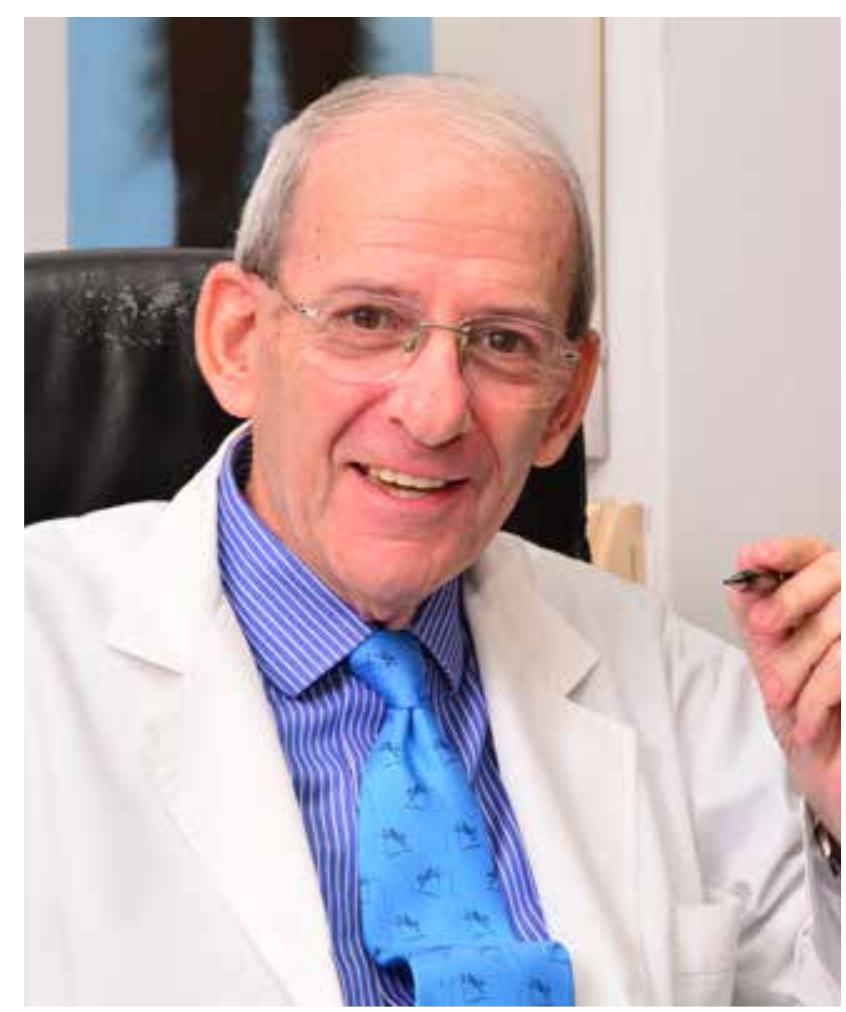

interior del país, en una Sociedad que hasta el momento era eminentemente centralista.

Publicó muchos trabajos de Investigación Clínica y fue pionero en Investigación Clínico-Farmacológica en Córdoba y en el país, dejando en esa ciudad una fundación que es un legado para sus pacientes, y una fuente de trabajo para jóvenes colegas que tuvieron la suerte de integrarse a ella e impregnarse cotidianamente de sus enseñanzas y espíritu de trabajo.

Estuvo en innumerables oportunidades a cargo de receptar el examen de la especialidad Reumatología tanto en la Provincia como en la Universidad de Córdoba, pero 
sólo el postulante al título o los que lo acompañábamos en esa tarea podemos hablar de su cordialidad, su trato afable y respetuoso, recordándonos siempre que esa Evaluación Final era parte del proceso de Enseñanza-Aprendizaje y no una exigencia torturante para el colega que había estudiado muchos meses para llegar a esa ansiada instancia.

Sólo los que tuvimos la suerte de trabajar en algún momento cerca de él, supimos que en la década de los 80 , cuando no existían los derechos de los pacientes, el Dr. Alberto Strusberg supo escuchar y contener sus demandas, entendiendo la importancia de las decisiones compartidas. Los estimuló a crear los grupos de Ayuda Mutua en Artritis Reumatoidea, que constituyeron la primera iniciativa a nivel nacional, creándose luego en la SAR el "Comité Comunitario" y armando más tarde un Comité multidisciplinario que fijó las normas para organizarlos. En 1992, los pacientes participaron por primera vez de un Congreso Argentino de Reumatología, en Carlos Paz.

Durante su presidencia en la SAR, además de organizar el V Congreso del Cono Sur y el Congreso Argentino de 1992, ideó la nominación de MAESTRO de la Reumatología Argentina, en reconocimiento a los educadores de la especialidad, título que recibiera a posteriori en 2010.

Por tantas actividades y tanto espíritu participativo, impactó en la vida de los que lo rodearon en algún momento (alumnos, colegas, discípulos, pacientes de cualquier ámbito y cualquier estrato social), pero al mismo tiempo vivificó plenamente el ser compañero, padre y abuelo, orientando el andar de sus hijos y nietos de la mano de su entrañable compañera Raquel.

Sé que con todo lo antes descripto no he reflejado la personalidad multifacética de Alberto M. Strusberg. Tal vez lo logre con una anécdota final, sobre una cena acaecida en diciembre de 2015 en un curso en Córdoba. Compartimos la mesa 12 especialistas de distintas edades y, obvio, distintas épocas. El Dr. Strusberg, como era habitual, lideró la conversación; se mostró informado, actualizado en todos los temas, médicos o no, de excelente humor, con muchos planes a futuro, y sorprendentemente a cada uno de nosotros nos recordó nuestro examen de especialista evaluado por él, detallando el año, el tema, y alguna anécdota especial ocurrida a cada uno. Corroboramos allí la importancia con que recibía a cada colega, con entrega afectuosa y escucha atenta, ahondando en los lazos que enriquecen la existencia, más allá de títulos o roles, y salimos comentando la reunión, y lo joven, vigente y actualizado que lo habíamos visto.

En febrero de 2016, atendiendo el consultorio como de costumbre, sintió algunas molestias, y se llegó rápidamente al diagnóstico de una enfermedad hematológica maligna, falleciendo en pocos días, el 6 de marzo de 2016.

Confío que estas palabras alcancen para completar los recuerdos de la mitad más vieja de la Reumatología argentina, y los contenidos de Google de la mitad más joven, y formen una semblanza más o menos completa del Dr. Strusberg, a quien ya estamos extrañando pero a quien seguramente recuperaremos cotidianamente en cada acto de nuestra vida profesional.

\section{Dra. Ida Exeni \\ Médica Reumatóloga, Ciudad de Córdoba.}

